\title{
Natural Disaster Mitigation on Elementary School Teachers: Knowledge, Attitude, and Practices
}

\author{
Setyo Eko Atmojo \\ ${ }^{1}$ Department of Elementary School Teacher Education, Universitas PGRI Yogyakarta, Indonesia \\ e-mail: setyoekoatmojo@yahoo.co.id ${ }^{1}$
}

\begin{abstract}
This study aims to analyze the level of knowledge, attitudes, and practice of teachers in disaster education in elementary schools. This study uses questionnaires distributed to teachers in disasterprone schools. The data taken are age, gender, subjects taught, recent education, experience in disaster education training, knowledge level, attitude, and practice of disaster education. Respondents who have a good knowledge level are $51.5 \%$, enough knowledge level is $39.4 \%$, and less knowledge level is $9.1 \%$. As many as $98.9 \%$ of respondents have a positive attitude and $1.1 \%$ have a negative attitude. There are $90.9 \%$ of respondents have ever taught and $9.1 \%$ have never taught disaster education. This study concludes that teachers of Elementary in disaster-prone schools generally have good knowledge of disaster education, agree that disaster education becomes part of the curriculum, and have taught disaster education to students.
\end{abstract}

Keywords: Knowledge, Attitudes, Practice, Disaster, Mitigation

\section{Introduction}

Indonesia is a country that is located at a meeting point of four tectonic plates, that is the Asian continental plates, the Australian continental plate, the Indian ocean plate, and the Pacific ocean plate. As a result, this country is prone to be hit by natural disasters. One of the disasters that threatened is volcano eruptions. This disaster is caused by the position of Indonesia which is in the "Ring of Fire", Indonesia has the most number of volcanoes in the world. It has 130 volcanoes which constitute $10 \%$ of the world total. From those volcanoes, 17 are still active (Lavigne et al., 2008). The area with a radius of 5 kilometers from the top of the volcano is prone to catastrophic volcanic eruptions. This vulnerability is caused by the very high potential for volcanic eruptions in Indonesia (Togatorop et al., 2016). The high risk of volcanic eruptions in Magelang Regency and its surroundings requires good disaster anticipation from the community. So far there has been no data showing the condition of knowledge, attitudes and practices of disaster mitigation owned by people in areas prone to volcanic eruptions in Magelang Regency. Knowledge of attitudes and practices of disaster mitigation can be formed properly through education in schools (Rahma, 2012; Body et al., 2018).

The high potential of volcanic eruption hazards must be balanced with knowledge of the attitudes and skills of disaster mitigation of the surrounding community. To be able to produce people who have knowledge, attitudes and skills in good disaster mitigation need a school with teachers who have good disaster knowledge. The right condition for providing disaster knowledge to the community is when they are at the elementary school level. The advantages of providing disaster knowledge at the primary school level are: (1) the results of education are long-lasting and long-term, (2) reach a large enough population for the future of the nation, and (3) is a very appropriate time to nurture social values and moral to students (Rusilowati \& Binadja, 2012). Providing disaster knowledge of course must be through elementary school teachers who have knowledge of good disaster mitigation attitudes and practices. So far, there is still no data showing how much competence in knowledge, attitudes and practices of disaster mitigation possessed by elementary school teachers in areas prone to the eruption of Mount Merapi (Setyowati, 2019; Wardani, 2019).

\footnotetext{
${ }^{*}$ Corresponding author.

Received 27 May 2020; Accepted 18 September 2020; Available online 25 March 2021 (C) 2020 JPI. All Rights Reserved
} 
Based on this it is very important to know the condition of knowledge, attitudes and practices of disaster mitigation possessed by teachers in primary schools in areas prone to volcanic eruptions of Mount Merapi. This research seeks to provide an overview of data on the knowledge, attitudes and skills of elementary school teachers both public and private. in Magelang district which is prone to volcanic eruptions of Mount Merapi. By knowing the data about the knowledge, attitudes and practices of disaster mitigation teachers will facilitate policy making for local governments related to disaster mitigation of the eruption of Mount Merapi.

Mount Merapi is one of the most active volcanoes in Indonesia (Wismaya \& Anjasmara, 2016). It is located on the border between the province of Central Java and Yogyakarta. Some of the most vulnerable areas affected by the eruption of Merapi volcano are the right area located on the slopes of this mountain, which are the district and the city of Magelang. It happens because it is located inthe lava dome of Mount Merapi. Mount Merapi is the youngest mountain in a series of volcanoes that lead south from Mount Ungaran. This mountain is formed due to activity in the Indo-Australian Plate subduction zone which moves down the Eurasian Plate causing the emergence of volcanic activity along the central part of Java Island. The current peak is not overgrown with vegetation due to high volcanic activity. This peak is growing on the southwest side of the peak of older Mount Batulawang.

The most powerful eruption of Mount Merapi which is recorded in modern history occurred on 15-20 April 1872. The deadly eruption lasted for 120 hours without pause. Hot clouds and falling material destroy entire settlements located at altitudes above 1,000 meters above sea level. Mount Merapi erupted again in 2010, beginning by the dismantling of lava plugs and continued eruptions without forming a lava dome. The continuous earthquake occurred ahead of the big eruption on 3 and 5 November, more powerful than the eruption on October 26 because it created a hot cloud that slid up to 15 kilometres through Gendol River. The spewed material reaches 150 million cubic meters. Based on data from the National Disaster Management Agency (30/11/2010), 61,154 people were displaced, 341 people were killed, and 368 people had to be hospitalized. The rush of hot clouds and falling material caused 3,307 houses, schools, community health centres, and markets are broken. The value of losses reached 4.23 trillion rupiahs. Lack of information about potential disasters leads to inappropriate knowledge and perception of disasters.

The right knowledge and perception about disasters must be possessed by all members of the community including the school community. In elementary schools prone to Merapi disasters, teachers must have good knowledge and attitude about mitigating volcanic eruptions. The high impact of the Merapi eruption requires teachers in elementary schools to have knowledge, attitudes and skills in mitigating volcanic eruptions. Knowledge, attitudes and experiences significantly influence community preparedness in facing the eruption of Mount Merapi (Permana \& Artikel, 2019; Khasanah, 2016).

Based on data from the Magelang Regency BPBD, the areas most prone to Merapi eruption include Shaman District, Sawangan District, Salam District, Muntilan District, Ngluwar District, Mungkid District and Borobur District. Based on these data, the schools in the region must be able to organize disaster learmoejning in schools. This disaster learning activity plays a vital role in disaster risk reduction efforts. To be able to carry out disaster learning to the maximum requires teachers who have a skap, knowledge and skills in mitigating the volcano disaster (Wardani, 2019).

A teacher who is skilled in disaster learning will be able to give birth to students who have the volcano eruption mitigation competency. This study aims to map the knowledge, attitudes and skills of teachers in mitigating volcanic eruptions at schools at the base of volcanic eruptions. After knowing the ability of teachers in disaster mitigation will facilitate schools and local governments in providing disaster mitigation training to teachers who lack knowledge of volcanic eruption disaster mitigation. By having good volcano eruption competence the teacher is able to carry out good disaster learning activities so that the results obtained by students are more optimal. Knowledge, attitudes and skills of teacher disaster mitigation are important and must be mastered properly so that teachers are able to carry out disaster learning in schools prone to Mount Merapi disasters properly and appropriately (Zahara, 2019; Kristiyaningrum, 2017). 
Disaster education is one of the internal solutions in society to reduce the impact of disasters, and familiarize people with being responsive and alert to disasters that occur. Disaster education has various forms ranging from community-based disaster management, disaster education to disaster-aware communities, as well as local community wisdom in disaster management. In practice, disaster learning accommodates the potential and social capital that exists in the community as resources in implementing disaster management programs. Communities are expected to be responsive and aware that they live in disasterprone areas (Howard et al., 2017). Based on the importance of learning disasters in schools, it is necessary to study the knowledge, attitudes and practices of learning disasters in schools prone to volcanic eruptions.

Based on research by Rusilowati \& Binadja (2012), learning disasters in schools in disaster-prone areas is an effective strategy for reducing disaster risk. Teachers play an important role in both curriculum planning and implementation. They are planners, implementers, and curriculum developers for their classes. This means that the success or failure of achieving educational goals is largely determined by the quality of teachers. The teacher has a strategic role to be able to convey appropriate information about natural disaster mitigation to students. One of the efforts to prevent the occurrence of many victims due to disasters that has been carried out in several areas is by holding a disaster prepared school program (Tsuji, H., \& Hatanaka, 2018; Dwiningrum \& Widiowati, 2014; Rahayuningsih \& Kristiawan, 2018). Until now, the program has been implemented in the form of an educational curriculum in several schools.

Disaster research has been carried out in the last ten years, some of the results of these studies indicate that the learning tools developed are appropriate for giving to students, and can improve students' understanding in recognizing and dealing with disasters. The tools developed are in the form of five features of the learning model such as: syllabus, lesson plans, learning methods, teaching materials, as well as the techniques and types of assessment developed covering science material for grades IV, V, VI SD and VII, VII, IX SMP. The five features are packaged in a Handbook for Teaching Natural Disasters Integrated in Science (for Teachers), Textbooks (for Students) and a supplement in the form of cartoon comics.

The tools developed are declared valid and effective to improve students' understanding of disasters. This can be seen from the test results obtained by students. The increase in student learning outcomes (gain) from pretest to posttest ranged from $53.5 \%$ to $80.3 \%$. For elementary school students the average increase is $68 \%$, for junior high school students grade VIII an average of $60 \%$ and $80 \%$ for grade IX students. The increase in learning outcomes is in the medium to high category. In general, the natural disaster learning model integrated in the science lesson with SETS vision developed in this study is suitable for application in schools, elementary and junior high schools (Rahayuningsih \& Kristiawan, 2018).

Disaster learning does not stop at preventive action, but must introduce post-disaster management methods. Students have the understanding to be active, proactive and creative which is needed to build a culture of Disaster Risk Reduction for long-term mitigation purposes. Perceptions of objective knowledge of disaster events still need to be strengthened in students. Outbound, which is one of the disaster education learning models, needs to be designed in an integrated manner in the process of learning at school without increasing the student's learning load. This model will make students more fun so that during the learning process there is no rejection and fear but will increase reliability and objective awareness of disaster events (Siti Irene Astuti D \& Sudaryono, 2010).

The third research conducted by (Masfuah et al., 2011) stated that first, the critical thinking skills of students taught by the SETS vision pair exchange model were better than those taught with the SETS vision classical discussion model. The learning process of exchanging pairs involves small groups so that active interaction occurs between students. Active interaction and exchange of opinions in small groups make learning more conducive and maximized so that it can foster students' critical thinking skills. Second, students' attitudes towards natural disasters taught by using the pair exchange model with SETS vision were better than the attitudes of students taught with the classical discussion model with SETS 
vision. Learning to exchange pairs with the SETS vision can develop students' attitudes and understanding of natural disasters.

The fourth research is a study entitled Disaster Education in Schools in Indonesia Based on Several Discipline Perspectives of Science conducted by Leli Honesti and Nazwar Djali and published in 2012 (Honesti \& Djali, 2012). The results of this study state that as a country with various types of disasters that never dropping out from time to time, then disaster education should be implemented in schools. Based on the point of view of the integration of knowledge (transdisciplinarity), the disaster curriculum can be integrated into several school subject matter which is strongly related to disaster. By looking at various points of view, disaster education can be inserted or included in related subject matter, including Science, Social Sciences, Science, Indonesian Language, Mathematics, and Religion. So that students can manage disasters properly and completely, thus disaster mitigation can be carried out well and have a domino effect on others outside the school environment. This study aims to analyze the level of knowledge, attitudes, and practice of teachers in disaster education in elementary schools.

\section{Method}

The study was conducted from July - December 2019 in several private schools in Magelang District using a descriptive quantitative design study conducted by a cross-sectional method. The sample size was calculated using a categorical descriptive formula and obtained a minimum sample of 97 people. The sample was selected by stratified random sampling method based on the accreditation of schools $A$ and $B$ which are listed on the official web of National Accreditation Boarding School / Madrasah, then selected 5 schools from each class of accreditation. The inclusion criteria are all teachers who have at least 1 year of teaching in the school. Exclusion criteria are teachers who are unwilling to follow this study and who fill in an incomplete questionnaire. The variables in this research are knowledge, attitude, and practice to disaster education. The data were collected after obtaining permission from Universitas PGRI Yogyakarta to Head of National Unity and Political Institution (Kesbangpol) Magelang District, Education Office of Magelang City, and headmasters from each school. After conducting a permit to the principal, eight schools were found willing to follow the study.

The instrument used in this study is a questionnaire that has passed the validity and reliability test to 41 respondents of elementary school teachers who are not part of this research study. After analyzing the data obtained value of Cronbach's alpha 0.705 . The data taken are age, gender, last education, subjects taught, experience in disaster education training, level of knowledge, attitude, and practice on disaster education. Knowledge is divided into three categories: good, enough and poor criteria with good categoryto answer the question correctly as much as $\geq 75 \%$, enoughcategoryto answer the question correctly as much as 56 $75 \%$, and poor categoryif answering questions correctly as much as $\leq 55 \%$. Attitudes are divided into two categories: positive and negative. Respondents are considered to have a positive attitude if a minimum score $\leq x<$ median, otherwise negative if median $\leq x \leq$ maximum score. The practice is divided into have doing and never doing categories. Respondents are considered to have done category if the score $\geq 1$ and never do category if score 0 . Data processing is using Microsoft Excel 2010 program. The results are presented in the form of tables to describe the variables studied

\section{Result and Discussion}

The data of this study were obtained through questionnaires that were distributed to 105 elected primary school teachers and six of them did not meet the inclusion criteria so that 99 teachers were obtained with the distribution as in Table 1. 
Table 1. Respondent Distribution

\begin{tabular}{lc}
\hline \multicolumn{1}{c}{ Schools Name } & The number of respondents \\
\hline Ma`arif Dukun Islamic Elementary School & 8 \\
Kanisius Prontakan Elementary School & 4 \\
Banyubiru1 Public Elementary School & 20 \\
Banyudono1 Public Elementary School & 15 \\
Dukun 1 Public Elementary School & 17 \\
Dukun 2 Public Elementary School & 18 \\
Muhammadiyah Dukun Integrative Elementary School & 7 \\
Mangunsoka Public Elementary School & 10 \\
\hline Total & \multicolumn{2}{c}{$\mathbf{9 9}$} \\
\hline
\end{tabular}

Table 1 shows that more respondents come from public elementary schools, which means the number of schools and teachers from public elementary school is more than the official private elementary school of the National Accreditation Board School.

Table 2. Respondents' Characteristics

\begin{tabular}{lcc}
\hline Characteristics & Number (n) & Percentage (\%) \\
\hline Age (year old) & 10 & 10 \\
$\leq 25$ & 64 & 65 \\
$26-45$ & 25 & 25 \\
$\geq 46$ & & \\
Gender & 42 & 42 \\
Male & 57 & 58 \\
Female & & 10 \\
Last education level & 10 & 86 \\
Diploma & 85 & 4 \\
Bachelor & 4 & 13 \\
Master & & 12 \\
Subject taught & 13 & 7 \\
Science & 12 & 5 \\
Religion & 7 & 61 \\
Civics & 5 & 2 \\
Sport & 60 & \\
Others (Mathematic, Indonesian & Language, & 17 \\
English, Local Content, Social) & 2 & 83 \\
Guidance \& Counseling Teacher & & \\
Experience of natural disaster training & 17 & \\
Ever & 82 & \\
Never & &
\end{tabular}

Table 2 shows that more respondents are in the 26-45 years age range. As for sex, more female respondents compared with male respondents. Viewed from the experience of disaster education training most respondents never followed and a small part who had attended disaster education training. 
Table 3. Knowledge Level

\begin{tabular}{lcc}
\hline Knowledge & Frequency & $\%$ \\
\hline Good & 51 & 51.5 \\
Enough & 39 & 39.4 \\
Poor & 9 & 9.1 \\
\hline Total & $\mathbf{9 9}$ & $\mathbf{1 0 0}$ \\
\hline
\end{tabular}

Based on Table 3, most respondents have good knowledge on disaster education, but there are some respondents who have enough knowledge and a fewwho has less knowledge.

Table 4. Level of Knowledge Based on Teached Subjects

\begin{tabular}{lccc}
\hline \multirow{2}{*}{ Subject } & \multicolumn{3}{c}{ Knowledge Level } \\
\cline { 2 - 4 } & Good & Enough & Poor \\
\hline Science & 8 & 5 & 0 \\
Religion & 7 & 1 & 4 \\
Sport & 1 & 3 & 1 \\
Civics & 4 & 3 & 0 \\
Guidance\&Counseling & 2 & 0 & 0 \\
Others & 29 & 27 & 4 \\
\hline Total & $\mathbf{5 1}$ & $\mathbf{3 9}$ & $\mathbf{9}$ \\
\hline
\end{tabular}

In Table 4, the level of knowledge of respondents based on the subjects being taught. Respondents who teach science and civics mostly have good knowledge but still, they have enough knowledge. The respondents who teach religion mostly have good knowledge but still, the others have less knowledge. Respondents who teach other subjects (Mathematics, Indonesian, English, Local Content, and Social) mostly have good knowledge but the rests are still enough and less. The respondents who teach Guidance and Counseling have good knowledge.

Table 5. Attitude Level

\begin{tabular}{lcc}
\hline Attitude & Frequency & $\%$ \\
\hline Positive & 98 & 98.9 \\
Negative & 1 & 1.1 \\
\hline Total & 99 & $\mathbf{1 0 0}$ \\
\hline
\end{tabular}

Based on Table 5, almost all respondents showed a positive attitude and only a small percentage of respondents showed a negative attitude toward the provision of education for disaster education to elementary school students. The level of knowledge of respondents on each question related to education disaster education. From twenty questions, sixteen questions reached $50 \%$ correct responses; on the other hand, four questions did not reach $50 \%$ correct answers. Few respondents know that the process of the disaster can be explained scientifically, disaster can be predicted, and they know the way of saving from a disaster and recovering both environmental and socialafter the disaster.

Respondent's attitude to each statement related to disaster education can be summed up into several things. Firstly, most respondents agree that disaster education has a role to build knowledge about disaster mitigation in the community and also to minimize casualties in the natural disaster. Secondly, most of the respondents agree that the materials that should be given to the education of disaster include materials related to natural sciences, social sciences, and geography. Thirdly, most respondents agree that disaster education is not only the responsibilityofNational Disaster Management Authoritybut also schools. Fourth, most respondents agree that disaster education should be taught by all teachers and parents. Fifth, 
most respondents agreed that disaster education should be a part of the Primary School curriculum.

Table 6. Practice Level

\begin{tabular}{lll}
\hline Practice & Frequency & $\%$ \\
\hline Ever & 90 & 90.9 \\
Never & 9 & 9.1 \\
\hline Total & $\mathbf{9 9}$ & $\mathbf{1 0 0}$ \\
\hline
\end{tabular}

Based on Table 6, most respondents have taught disaster education to elementary students in disaster-prone areas and only a few respondents who never taught disaster education to their children.

From the data obtained, the majority of teachers respondents have good knowledge of education disaster. This is similar to research from (Imamura et al., 2012) in Padang, Indonesia. They say junior high school teachers have a good knowledge of the Tsunami disaster. However, unlike research conducted (Mojtahedi, M., \& Oo, 2019) and (Gunawan \& Setiabudi, 2020) that says people in the disaster area have low knowledge of disaster education. The study estimates that the low knowledge of respondents is influenced by the culture where every citizen is not well informed about disaster education as early as possible. The differences in the results of this study may be due to cultural differences, levels of education, and access to information resources related to disaster education.

Knowledge is the result of knowing from manthat answers the question "what". Knowledge is the result of using their five senses which give an impression in the human mind and is not beliefs, superstitions, and misinformations (Wade \& Kidd, 2019; Ekerholt \& Bergland, 2019; Steben et al., 2019; Hinshaw et al., 2013). The various phenomena encountered and obtained by the human sense through observation are other notion of knowledge (Behrens et al., 2018). The factors that influence the level of knowledge include education, experience, socio-economic, and culture (Khan et al., 2019; Corley, E. A., Bozeman, B., Zhang, X., \&Tsai, 2017; Hălbac-Cotoară-Zamfir et al., 2019; Hajhosseini et al., 2016; Kainuwa et al., 2013). In this study, the researchers also looked for information related to these factors from each respondent. The majority of teacher education subject to this research is Diploma $86 \%(\mathrm{n}=$ $85)$ and the rest are master $4 \%(n=4)$ and $10 \%(n=10)$, where the education level is quite high. In addition, based on subjects taught, teachers who teach Science has good knowledge and enoughbecause the subjects taught are quite similar to disaster education materials. In contrast, teachers of religious subjects still have bad knowledge because this subject do not thoroughly discuss disaster education materials.

In this study, there are many respondents who have less knowledge about disaster, mitigation, disaster adaptation education and how to response it. The majority of respondents do not know that mitigation, adaptation, and responsibility are different things. Indonesian people still often think that these three things, which are similar. Lack of knowledge can be caused bylack of reading and digging information about it from a reliable source (Yani T. \& Oikawa, 2019; Mardin \& Shen, 2019). The majority of respondents did not know that there were signs that could indicate a disaster that could predict the strength and impact of the disaster. Researchers estimate it due to two things, firstly, it is caused by social and cultural influences in Indonesia. some areas in Indonesia, the community has an assumption thatthe incident of disaster associated with a mystical event. The majority of respondents are also unaware of the first response to be taken during a disaster. The importance of elementary school teachers to understand well the above things in order to explain to their students. As a result, the students do not seek and explore about disaster mitigation by themselves andget incorrect information. Therefore, it is very important to educate elementary school students and teachers about natural disasters.

The definition of a disaster according to Law Number 24 of 2007 is an event or series of events that threatens and disrupts the life and livelihood of the community which is caused, either by natural factors and / or non-natural factors or human factors, resulting in human 
casualties, environmental damage, property loss. objects, and psychological impact. This definition states that disasters are caused by natural, non-natural, and human factors. Therefore, Law Number 24 of 2007 also defines natural disasters, non-natural disasters and social disasters.Natural disasters are disasters caused by events or a series of events caused by nature, including among others, earthquakes, tsunamis, volcanic eruptions, floods, droughts, hurricanes and landslides. Non-natural disasters are disasters caused by nonnatural events or series of events, which include technological failure, modernization failure, epidemics, and disease outbreaks. A social disaster is a disaster that is caused by an event or series of events caused by humans, including social conflicts between groups or between communities, and terror.

The majority of this study respondents have a positive attitude towards disaster education and agree that discourse education should be part of the school curriculum. Almost all respondents agree that before implementing to the curriculum, teachers should be provided with disaster education training. It is also found in the previous study mentioned by (Imamura et al., 2012). They say that as many as $94.6 \%$ of respondents agreed that disaster education should be taught in schools and be part of the school curriculum and the expectation of respondents to be given disaster training so that it can teach the students well. Similarly, the results of research conducted (Horney et al., 2017; Xu, D., Hazeltine, B., Xu, J., \& Prasad, 2018; He, F., \& Zhuang, 2006; Reffiane, F., \& Saptaningrum, 2014). The results say that respondents have good knowledge of disaster education and respondents agree that disaster education should be part of the curriculum.

Based on the results of the study, it is known that $28 \%$ of respondents do not agree that disaster learning has not been able to minimize the occurrence of disaster risks. Research (Ruizgarcia, 2019; Ramadhani, 2020) shows that there is a relationship between the intensity level of implementing disaster learning in schools with increased mitigation, adaptation and responsibility for natural disasters. The study estimates that elementary school teachers' high knowledge of disaster can be conveyed and well received by elementary school students so that it can increase disaster resilience in communities in areas prone to volcanic disasters.

The implementation of disaster learning is part of the mitigation of natural disasters from the eruption of Mount Merapi. This disaster learning activity still really needs to be implemented and improved in primary schools in the coming years. This disaster learning activity needs to be continued, especially for schools in disaster-prone areas. It is a necessity that learning about disasters and efforts to mitigate disasters from the eruption of Mount Merapi must be carried out in schools that are prone to disasters. Through teachers who master the knowledge, practices and skills of disaster mitigation on Mount Merapi, they will be able to carry out disaster learning properly. Through good learning activities for volcanic eruption disasters, it will be able to increase students' knowledge and skills about mitigating natural disasters from volcanic eruptions. Knowledge, attitudes and good natural disaster mitigation skills of teachers are the government's social capital in facing the threat of a catastrophic eruption of Mount Merapi in the next five to ten years, whose occurrence is very difficult to predict when it will occur. Community awareness, concern, readiness, alertness and responsibility, especially for those who live in the ring of fire and the meeting of the three tectonic plates of the world which are influenced by three movements, namely the movement of the Sundanese system in the west, the movement of the Asian peripheral system East, and the Australian circumcision movement which is very vulnerable to the threat of volcanic eruptions needs to be increased.

The limitations of this study are the data collection method using a questionnaire and many statements that may not be understood by respondents. The method of collecting data for practice variables using a questionnaire is also a limitation because there is the possibility of bias. There were three schools that refused to be supervised when filling out the questionnaire so that researchers could not prevent triadics

\section{Conclusions and Suggestions}

Elementary school teachers in MagelangDistrict generally have a good knowledge of disaster education. The level of knowledge is thought to be influenced by the last level of 
educational factors. Primary School Teachers agree that disaster education should be a part of the curriculum and they have ever taught disaster education to students. Researchers estimate the community's and students'lack of knowledge about the disaster and mitigation efforts caused by several factors and the teacher education factor in the school is one of them.

\section{Acknowledgements}

Thanks to Research Institutions and Community Service Universitas PGRI Yogyakarta for funding this research. Political Institution (Kesbangpol) Magelang District, Education Office of Magelang City, and headmasters from each school

\section{References}

Behrens, T. E. J., Muller, T. H., Whittington, J. C. R., Mark, S., Baram, A. B., Stachenfeld, K. L., \& Kurth-Nelson, Z. (2018). What Is a Cognitive Map? Organizing Knowledge for Flexible Behavior. Neuron, 100 (2), 490-509. https://doi.org/10.1016/j.neuron.2018.10.002.

Body, R., Rifwan, F., \& Silalahi, J. (2018). Persepsi Guru SMK Jurusan Bangunan Sekota Padang Tsunami. CIVED (Journal of Civil Engineering and Vocational Education), 5(1), 2151-2157. https://doi.org/103.216.87.80.

Corley, E. A., Bozeman, B., Zhang, X., \&Tsai, C. C. 2019. (2017). The expanded scientific and technical human capital model: the addition of a cultural dimension. The Journal of Technology Transfer, 681-699. https://doi.org/10.2307/23324215.

Dwiningrum, S. I. A., \& Widiowati, R. (2014). School Resiliency and Social Capital of Regrouping Policy After Merapi Eruption in The Special District of Yogyakarta of Indonesia (A Case Study at SD Umbulharjo 2, Sleman, Special District of Yogyakarta). International Journal of Asian Social Science, 4(4), 510-525. http://www.aessweb.com/journals/5007.

Ekerholt, K., \& Bergland, A. (2019). Learning and knowing bodies: Norwegian psychomotor physiotherapists' reflections on embodied knowledge. Physiotherapy Theory and Practice, 35(1), 57-69. https://doi.org/10.1080/09593985.2018.1433256.

Gunawan, E. O., \& Setiabudi, D. H. (2020). Perangkat Lunak Logistik Kemanusiaan untuk Memantau Distribusi Bantuan Korban Bencana Alam. Jurnal Infra, 8(1), 335-339. http://publication. petra.ac.id/index.php/teknik-informatika/article/view/9871.

Hajhosseini, M., Zandi, S., Hosseini Shabanan, S., \& Madani, Y. (2016). Critical thinking and social interaction in active learning: A conceptual analysis of class discussion from Iranian students' perspective. Cogent Education, 3(1), 1-9. https://doi.org/10.1080/2331186X.2016.1175051.

Hălbac-Cotoară-Zamfir, R., Keesstra, S., \& Kalantari, Z. (2019). The impact of political, socioeconomic and cultural factors on implementing environment friendly techniques for sustainable land management and climate change mitigation in Romania. Science of the Total Environment, 654, 418-429. https://doi.org/10.1016/j.scitotenv.2018.11.160.

He, F., \& Zhuang, J. 2016. Balancing pre-disaster preparedness and post-disaster relief. European Journal of Operational Research, 252 (1), 246-256. https://doi.org/10.1016/j.ejor.2015.12.048.

Hinshaw, G., Larson, D., Komatsu, E., Spergel, D. N., Bennett, C. L., Dunkley, J., Nolta, M. R., Halpern, M., Hill, R. S., Odegard, N., Page, L., Smith, K. M., Weiland, J. L., Gold, B., Jarosik, N., Kogut, A., Limon, M., Meyer, S. S., Tucker, G. S., ... Wright, E. L. (2013). Nine-year wilkinson microwave anisotropy probe (WMAP) observations: Cosmological parameter results. Astrophysical Journal, Supplement Series, 208(2). https://doi.org/10.1088/0067-0049/208/2/19.

Honesti, L., \& Djali, N. (2012). Pendidikan Kebencanaan di Sekolah - Sekolah di Indonesia Berdasarkan Beberapa Sudut Pandang Disiplin Ilmu Pengetahuan. Jurnal Momentum, 12(1), 51-56. http://e-journal.itp.ac.id/index.php/momentum/article/view/88. 
Horney, J., Nguyen, M., Salvesen, D., Dwyer, C., Cooper, J., \& Berke, P. (2017). Assessing the Quality of Rural Hazard Mitigation Plans in the Southeastern United States. Journal of Planning Education and Research, 37(1), 56-65. https://doi.org/10.1177/0739456X16628605.

Howard, A., Agllias, K., Bevis, M., \& Blakemore, T. (2017). "They'll tell us when to evacuate": The experiences and expectations of disaster-related communication in vulnerable groups. International Journal of Disaster Risk Reduction, 22(October 2016), 139-146. https://doi.org/10.1016/j.ijdrr.2017.03.002.

Imamura, F., Muhari, A., Mas, E., Pradono, M. H., Post, J., \& Sugimoto, M. (2012). Tsunami Disaster Mitigation by Integrating Comprehensive Countermeasures in Padang City, Indonesia. Journal of Disaster Research, 7(1), 48-64. https://www.fujipress.jp/jdr/dr/dsstr000700010048/.

Kainuwa, A., Binti, N., \& Yusuf, M. (2013). Influence of Socio-Economic and Educational Background of Parents on their Children's Education in Nigeria. International Journal of Scientific and Research Publications, 3(10), 2250-3153. http://www.ijsrp.org/research-paper-1013/ijsrp-p2258.pdf.

Khan, A., Baharul Islam, K. M., \& Mitra, A. (2019). Exploring the status of community information and training for disaster preparation and mitigation practices: An appraisal of 2013 flash flood in Uttarakhand. International Journal of Emergency Management, 15(2), 147-165. https://doi.org/10.1504/IJEM.2019.099373.

Khasanah, I. (2016). Kajian Pengetahuan, Sikap dan Tindakan Kesiapsiagaan Siswa SMP Dalam Menghadapi Bencana Erupsi Gunung Merapi di Kabupaten Magelang. (Doctoral Dissertation, Universitas Negeri Semarang).

Kristiyaningrum, D. H. (2017). Disabo Berbasis Komik Sebagai Media Pendidikan Kebencanaan Di Sekolah Dasar Peningkatan. Jurnal Dialektika Jurusan PGSD, 7(2), 1-12. https://journal.peradaban.ac.id/index.php/jdpgsd/article/view/146.

Lavigne, F., Coster, B. De, Juvin, N., \& Flohic, F. (2008). People' s behaviour in the face of volcanic hazards: Perspectives from Javanese communities, Indonesia. Journal of Volcanology and Geothermal Research 172, 273-287. https://doi.org/10.1016/j.jvolgeores.2007.12.013.

Mardin, R., \& Shen, Z. (2019). Integrated Criteria for Flood Disaster Mitigation in Indonesian Urban Masterplan; Housing and Settlement Suitability Case in Palu Urban Masterplan. In Urban Planning and Water-related Disaster Management.127-153. https://doi.org/10.1007/978-3-319-90173-2 8.

Masfuah, A. Rusilowati, S. (2011). Pembelajaran Kebencanaan Alam dengan Model Bertukar Pasangan Bervisi SETS untuk Menumbuhkan Kemampuan Berpikir Kritis Siswa. Jurnal Pendidikan Fisika Indonesia, 7(2). 245-253. https://doi.org/10.15294/jpfi.v7i2.1083.

Mojtahedi, M., \& Oo, B. L. (2019). Disaster risk management approaches in construction and built environment: A research collaboration networks perspective. International Journal of Disaster Resilience in the Built Environment, 1-28. https://doi.org/10.1108/IJDRBE06-2019-0032.

Permana, S. A., \& Artikel, I. (2019). Mitologi Sebagai Pendidikan Kebencanaan Dalam Memahami Erupsi Gunung Merapi. Refleksi Edukatika: Jurnal IImiah Kependidikan, 9(2), 121-127. https://doi.org/10.24176/re.v9i2.3277.

Rahayuningsih, S., \& Kristiawan, I. (2018). Kemampuan Berpikir Kritis Siswa Dalam Menyelesaikan Masalah Matematika. Conference on Innovation and Application of Science and Technology (CIASTECH 2018), September, 245-253. http://publishingwidyagama.ac.id/ejournal-v2/index.php/ciastech/article/download/629/581.

Rahma, A. (2012). Implementasi Program Pengurangan Risiko Bencana (PRB ) Melalui Pendidikan Formal. Jurnal VARIDIKA, 30(1), 1-11. DOI: 10.23917/varidika.v30i1.6537.

Ramadhani, F. P., \& Manusia, F. E. (2020). Analisis Gender dalam Upaya Adaptasi dan 
Mitigasi Perubahan Iklim. Jurnal Sains Komunikasi dan Pengembangan Masyarakat [JSKPM], 4(2), 155-166.https://doi.org/10.29244/jskpm.4.2.155-166.

Reffiane, F., \& Saptaningrum, E. 2014. (2014). The Analysis Of Teachers ' Book For Learning Natural Disaster Mitigation Of The Earth As A Model Disaster Management Sub Theme "Events In The Life" With Theme "Natural Event." International Conference On Mathematics, Science, and Education, 2014(ICMSE), 21-24.

Ruizgarcia, V. (2019). Engaging national policy makers in ecosystem based disaster risk reduction through social learning: Lessons from workshops in Africa, oceania, Latin America and the Caribbean. International Journal of Disaster Risk Redaction, 45. https://doi.org/https://doi.org/10.1016/j.ijdrr.2019.101463.

Rusilowati, A., \& Binadja, A. (2012). Mitigasi Bencana Alam Berbasis Pembelajaran Bervisi Science Environment Technology and Society. Jurnal Pendidikan Fisika Indonesia, 8(1), 51-60. https://doi.org/10.15294/jpfi.v8i1.1994.

Setyowati, D. L. (2019). Pendidikan Kebencanaan. Semarang: Universitas Negeri Semarang Press.

Siti Irene Astuti D and Sudaryono, 2010. PeranSekolah dalam Pembelajaran Mitigasi Bencana. Jurnal Dialog Penanggulangan Bencana. Volume 1 No. 1/2010. http://staffnew.uny.ac.id/upload/131808673/penelitian/jurnal-dialog-penanggulanganbencana.pdf.

Puspitorini, P., \& Sulistyawati, Y. (2020). Sosialisasi dan Simulasi Tanggap Bencana Gunung Meletus dan Banjir Desa Sumberagung Kecamatan Gandusari. Abdimas Universal, 2(1), 44-48. https://doi.org/10.36277/abdimasuniversal.v2i1.49.

Steben, M., Durand, N., Guichon, J. R., Greenwald, Z. R., McFaul, S., \& Blake, J. (2019). A National Survey of Canadian Adults on HPV: Knowledge, Attitudes, and Barriers to the HPV Vaccine. Journal of Obstetrics and Gynaecology Canada, 41(8), 1125-1133.e6. https://doi.org/10.1016/j.jogc.2019.05.005.

Togatorop, PM, Subiyanto, S., \& Wijaya, A. (2016). Pemetaan Potensi Bencana Aliran Lava Gunung Sinabung Menggunakan Citra Aster Gdem. Jurnal Geodesi Undip, 5(2), 8796. https://ejournal3.undip.ac.id/index.php/geodesi/article/view/11525.

Tsuji, H., \& Hatanaka, Y. 2018. GEONET as Infrastructure for Disaster Mitigation. Journal of Disaster Research, 13(3), 424-432. https://doi.org/10.20965/jdr.2018.p0424.

Wade, S., \& Kidd, C. (2019). The role of prior knowledge and curiosity in learning. Psychonomic Bulletin and Review, 26(4), 1377-1387. https://doi.org/10.3758/s13423019-01598-6.

Wardani. (2019). Implementasi Metode Pembelajaran Geografi Tentang Pendidikan Mitigasi Bencana Di SMA Negeri 1 Sleman (Doctoral Dissertation, UNNES).

Wismaya, Y. G., \& Anjasmara, I. M. (2016). Analisis Deformasi Gunung Merapi Berdasarkan Data Pengamatan GPS Februari-Juli 2015. Jurnal Teknik ITS, 5(2), A427-A431. https://www.neliti.com/publications/192182/analisis-deformasi-gunung-merapiberdasarkan-data-pengamatan-gps-februari-juli-2\#cite.

Xu, D., Hazeltine, B., Xu, J., \& Prasad, A. 2018. (2018). Public participation in NGO-oriented communities for disaster prevention and mitigation (N-CDPM) in the Longmen Shan fault area during the Wenchuan and Lushan earthquake periods. Journal Environmental Hazards, 17(4), 371-395. https://doi.org/10.1080/17477891.2018.1491382.

Yani T., A., \& Oikawa, S. (2019). Increasing Creative and Innovative Thinking Ability through The Strengthening of Character Education in Probability Theory Course. JETL (Journal Of Education, Teaching and Learning), 4(1), 163. https://doi.org/10.26737/jetl.v4i1.990.

Zahara. (2019). Peran Sekolah Dalam Pendidikan Migitasi Bencana Di Sekolah Menengah Atas. Pencerahan, 13(2),144-155.

http://jurnalpencerahan.org/index.php/jp/article/view/5. 